Egyptian Veterinary Medical Society

of Parasitology Journal

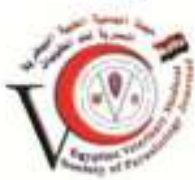

\title{
Original Article \\ Phenotypic and pathological characterizations of different Sarcocystis species in donkeys
}

Mona Mohammed I.
Abdel Rahman ${ }^{1}$ and
Heba M. Abdel-Ghany ${ }^{2}$
${ }^{1}$ Parasitology and
${ }^{2}$ Pathology Dept.,
Faculty of Vet. Med.,
Zagazig University.
Zagazig,Egypt
Corresponding author:
mona_111_para@yahoo.co
m
$\mathbf{0 1 1 2 4 9 8 3 3 1 0}$

Mona Mohammed I.

Abdel Rahman ${ }^{1}$ and

${ }^{1}$ Parasitology and

${ }^{2}$ Pathology Dept.,

Faculty of Vet. Med. Zagazig University.

01124983310

\begin{abstract}
:
This study aimed to record the prevalence of different Sarcocystis spp., demonstrate their morphological characters by laboratory, histopathological and immunohistochemical techniques, also to investigate the pathological lesions in esophagus, heart, and brain samples collected from naturally infected donkeys in Egypt. The current study identified four Sarcocystis spp. (S. bertrami, S. equicanis, S. asinus and S. fayeri) in meat samples and $S$. neurona in the brain of the examined donkeys. Examination of meat samples showed macroscopic tissue cysts of $S$. bertrami and microscopic tissue cysts of $S$. equicanis/S. asinus and $S$. fayeri. According to the thickness of the cyst wall, Sarcocystis spp. were divided into smooth thin walled $S$. bertrami, ciliated thin walled $S$. equicanis/S. asius and striated thick walled $S$. fayeri. Also, immunohistochemical (IHC) examination showed strong labeled schizonts and cyst wall of $S$. neurona, while the bradyzoites appeared negative staining. Pathological examination revealed degeneration of muscles with intermuscular edema and few mononuclear inflammatory cells, but brain tissue showed perivascular lymphocytic cuffing and satellitosis with developing schizonts. The current study concluded that the accurate recognition about Sarcocystis spp. in donkeys would be helpful in their treatment, prevention and control measures.
\end{abstract}

Keywords: bertrami, donkey, equicanis, fayeri, immunohistichemical, neurona.

\section{INTRODUCTION}

Sarcocystis spp. cysts were noticed by Miescher (1843) for the first time in mouse muscles in Switzerland. Such nomenclature was derived from finding them encysted (cyst) and localized in the muscles (sarco) of the intermediate hosts Dubey et al. 2016a; Dubey et al. 1989. The cysts were formed through endodyogeny of merozoites and could reproduce through endodyogeny (production of metrocytes with a pair of 
daughter nuclei) and endopolygeny (production of multinucleated metrocytes) Slapeta et al. 1999. Sarcocystis spp. is a common protozoan parasite and distributed worldwide in muscles of mammals and birds. Four species; $S$. bertrami, $S$. equicanis/S. asinus, $S$. fayeri and $S$. neurona were recorded in equine Levine and Tadros 1980. Dogs act as final hosts for $S$. bertrami, $S$. equicanis/S. asinus, and $S$. fayeri, while opossums act as final hosts for $S$. neurona Dubey et al. 2016a.

S. neurona investigated in a wide range of hosts. If their schizonts were detected in the host, it is considered as an aberrant host, while if the mature cysts were investigated, the host is considered intermediate Dubey et al. 2015. The schizonts had been found only in brain Dubey et al. 2001, but their cysts might be found in brain, cardiac or skeletal muscles Miller et al. 2009. $S$. neurona is the most pathogenic species in equine where it induce equine protozoal myeloencephalitis (EPM). The manifested clinical signs vary according to the involved area in CNS from weakness, facial paralysis, dysphagia, and gait abnormalities to seizures Dubey et al. 2001; Dubey et al. 2015. Also, Aleman et al. 2015 reported that $S$. fayeri infection in equine induced eosinophilic myositis and cardiomyopathy, which manifested by weight losses, stiffness, lethargy, muscle pain, swollen tongue and dysphagia.
Determination of different Sarcocystis spp. in equines is still confused Dubey et al. 2016a. They included $S$. bertrami, $S$. equicanis, $S$. fayeri and $S$. neurona. Zeng et al. 2018 found that Sarcocystis spp. in horses and donkeys were closely related based upon their phenotypic characters and coxI sequences and so they suggested both horses and donkeys had the same Sarcocystis spp. Many authors studied sarcocystosis in horses, but little data was known about donkeys and so this study is dealing with Sarcocystis spp. prevalence, morphological characterization of different Sarcocystis spp., and pathological findings in meat and brain samples of naturally infected donkeys in Egypt.

\section{MATERIAL AND METHODS}

\section{Samples collection}

Meat and brain samples were collected from 80 and 20 slaughtered donkeys, respectively in Giza Zoo, Giza Governorate, Dokki, Egypt. Samples were transported in an ice tank to Zagazig University, Faculty of Veterinary Medicine, Parasitology Department for further examinations. This study was approved with number ZUIACUC/2/F/75/2018 by ZU-IACUC Committee, Zagazig University, Egypt

\section{Laboratory examination}

By naked eye, meat samples were examined for macroscopic cysts. Small pieces of meat were crushed between two glass slides 
and examined under the light microscope to detect microscopic cysts. Also, small pieces of brain were squeezed on glass slides and then stained with Giemsa stain to observe the released bradyzoites or metrocytes under the oil immersion lens.

\section{Pathological examination}

Meat and brain samples were collected from slaughtered donkeys for detection of Sarcocystis spp. The collected specimens were fixed in $10 \%$ buffered neutral formalin solution, processed, stained and prepared for microscopical examination according to the descriptions of Suvarna et al. 2013.

\section{Immunohistochemical (IHC) examination}

The de-paraffinized sections of brain and meat samples were incubated with polyclonal goatantibodies against $S$. neurona (VMRD, Inc. Pullman, WA) Soldati et al. 2004 and A streptavidinimmunoperoxidase labeling (Sigma Chemicals, St. Louis, US) was used to distinguish positive immune reactions Kiupel et al. 2003. Positive control was prepared from positively infected tissue sections incubated with polyclonal antibodies against $S$. neurona, while the negative control was prepared from sections incubated with non-immune sera. The procedures were completed as the description of Dubey et al. 2016a. The measurements of length, width, and cyst wall thickness of Sarcocystis spp. were performed by a calibrated eye piece micrometer.

\section{RESULTS}

\section{Prevalence}

Visual and light microscopical examination of fresh and stained sections (H\&E or $\mathrm{IHC}$ ) of meat and brain samples showed detection of S. bertrami, S. equicanis/S. asinus, $S$. fayeri, and $S$. neurona. Their prevalence were listed in Tables (13).

\section{Morphological identification}

Examination of meat samples showed macroscopic tissue cysts of $S$. bertrami and microscopic tissue cysts of $S$. equicanis/S. asinus and $S$. fayeri. The mature cysts appeared septated, spindleshaped, contained numerous bradyzoites and surrounded by cyst wall. According to the thickness of the cyst wall, Sarcocystis spp. were divided into smooth thin walled $S$. bertrami, ciliated thin walled $S$. equicanis/S. asinus and striated thick walled $S$. fayeri. In $S$. fayeri, the immature cysts contained numerous metrocytes and surrounded by granular cyst wall. The stained brain smears showed developed metrocytes with granular basophilic nucleus. The morphological identification of Sarcocystis spp. in donkey's meat was recorded during light microscopical examination of fresh and stained sample sections with H\&E (Fig. 1\&2).

\section{Immunohistochemical (IHC)} examination

The deparaffinized brain samples from donkeys are the only 
Sarcocystis spp. positive immune reactions against polyclonal antiserum of $S$. neurona. The irregular-shaped schizonts, the cyst wall and the septa of mature cysts appeared strongly labeled, while the bradyzoites showed negative staining (Fig. 2). The measurements of different Sarcocystis spp. in the examined samples from brain and meat of donkeys were recorded and showed in Table 4.

\section{Pathological examination}

The heart exhibited multiple basophilic mature cross and elongated intra muscular cysts containing banana shape bradyzoites. Few mononuclear inflammatory cells were present around some cysts. Acute degeneration of the cardiac muscle and intermuscular edema were detected. Hyaline thickening of the blood vessel with endotheliosis were observed (Fig. 3).

The examined oesophagus tissues showed microscopic, elongated and cross cysts containing basophilic bradyzoites. Immature cysts were also observed between the muscles. Degeneration of muscles with intermuscular edema was detected (Fig. 4).
The examined brain tissues revealed perivascular lymphocytic cuffing with scattered glia cells in the white and gray matter (Fig. 5A). Satellitosis and demyelination were detected in the white matter (Fig. 5B).Encophalomalacia represented by depletion of certain part of brain tissue with gliosis were observed (Fig. 5C). Developing schizonts were noticed (Fig. 5D). 
Table 1: Total prevalence of Sarcocystis spp. in the examined donkeys

\begin{tabular}{|l|c|c|c|}
\hline Item & $\begin{array}{c}\text { Examined } \\
\text { numbers }\end{array}$ & Positive numbers & Positive \% \\
\hline Meat samples & 80 & 67 & $83.75 \%(67 / 80)$ \\
\hline Brain samples & 20 & 6 & $30 \%(6 / 20)$ \\
\hline Total & 100 & 73 & $73 \%(73 / 100)$ \\
\hline
\end{tabular}

Table 2: Prevalence of single and mixed infections with muscular Sarcocystis spp. in donkeys

\begin{tabular}{|l|c|c|c|}
\hline Item & Positive \% & Single & Mixed \\
\hline Infection type & $83.75(67 / 80)$ & $25.37 \%(17 / 67)$ & $74.63 \%(50 / 67)$ \\
\hline
\end{tabular}

Table 3: Prevalence of different Sarcocystis spp. in the examined donkeys

\begin{tabular}{|l|c|c|c|l|}
\hline Item & S. bertrami & S. equicanis & S.fayeri & \multicolumn{1}{|c|}{ S. neurona } \\
\hline Prevalence\% & $80.60 \%$ & $85.07 \%$ & $50.75 \%$ & $30 \%(6 / 20)$ for \\
(numbers) & $(54 / 67)$ & $(57 / 67)$ & $(34 / 67)$ & schizonts \\
& & & & $5 \%(1 / 20)$ for cysts \\
\hline
\end{tabular}

Table 4: Measurements of different Sarcocystis spp. in the examined donkeys

\begin{tabular}{|c|c|c|c|c|}
\hline Item & S. bertrami & S. equicanis & S.fayeri & S. neurona \\
\hline Length & $\begin{array}{l}5-8 \mathrm{~mm} \\
(6.5 \mathrm{~mm})\end{array}$ & $\begin{array}{c}0.5-2.3 \mathrm{~mm} \\
(1.2 \mathrm{~mm})\end{array}$ & $\begin{array}{c}450.8-600 \\
\mu \mathrm{m} \\
(467 \mu \mathrm{m})\end{array}$ & $175 \mu \mathrm{m}$ \\
\hline Width & $\begin{array}{l}0.4-1 \mathrm{~mm} \\
(0.7 \mathrm{~mm})\end{array}$ & $\begin{array}{c}50-150 \mu \mathrm{m} \\
(100 \mu \mathrm{m})\end{array}$ & $\begin{array}{c}47.2-75.5 \mu \mathrm{m} \\
(467 \mu \mathrm{m})\end{array}$ & $40 \mu \mathrm{m}$ \\
\hline $\begin{array}{l}\text { Cyst wall } \\
\text { thickness }\end{array}$ & $\begin{array}{c}0.3-0.8 \mu \mathrm{m} \\
(0.5 \mu \mathrm{m})\end{array}$ & $\begin{array}{c}0.7-1.5 \mu \mathrm{m} \\
(0.9 \mu \mathrm{m})\end{array}$ & $\begin{array}{c}3.4-6.5 \mu \mathrm{m} \\
(5.5 \mu \mathrm{m})\end{array}$ & $0.5 \mu \mathrm{m}$ \\
\hline
\end{tabular}




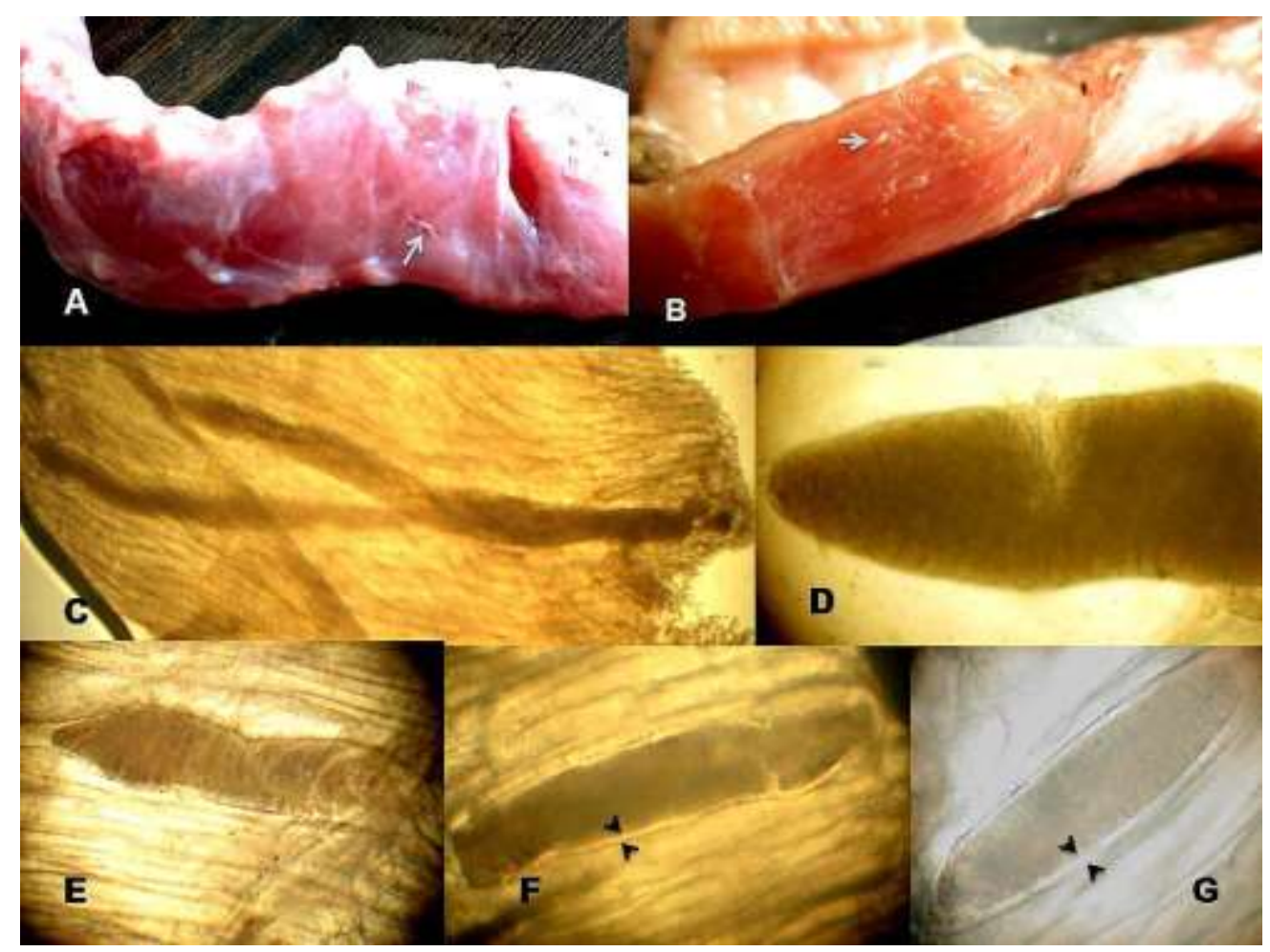

Fig. 1: A\&B: Photographs showing macroscopic cysts of $S$. bertrami in donkey esophagus (arrow); C: Fresh cysts of $S$. bertrami under light microscope (X40); D: higher magnification of $S$. bertrami showing well developed septa (X100); E: Fresh cysts of $S$. equicanis/S. asinus(X100) and F\&G: Fresh cysts of $S$. fayeri demonstrated the thick cyst wall (arrowheads, $\mathrm{X} 100$, Digital camera).

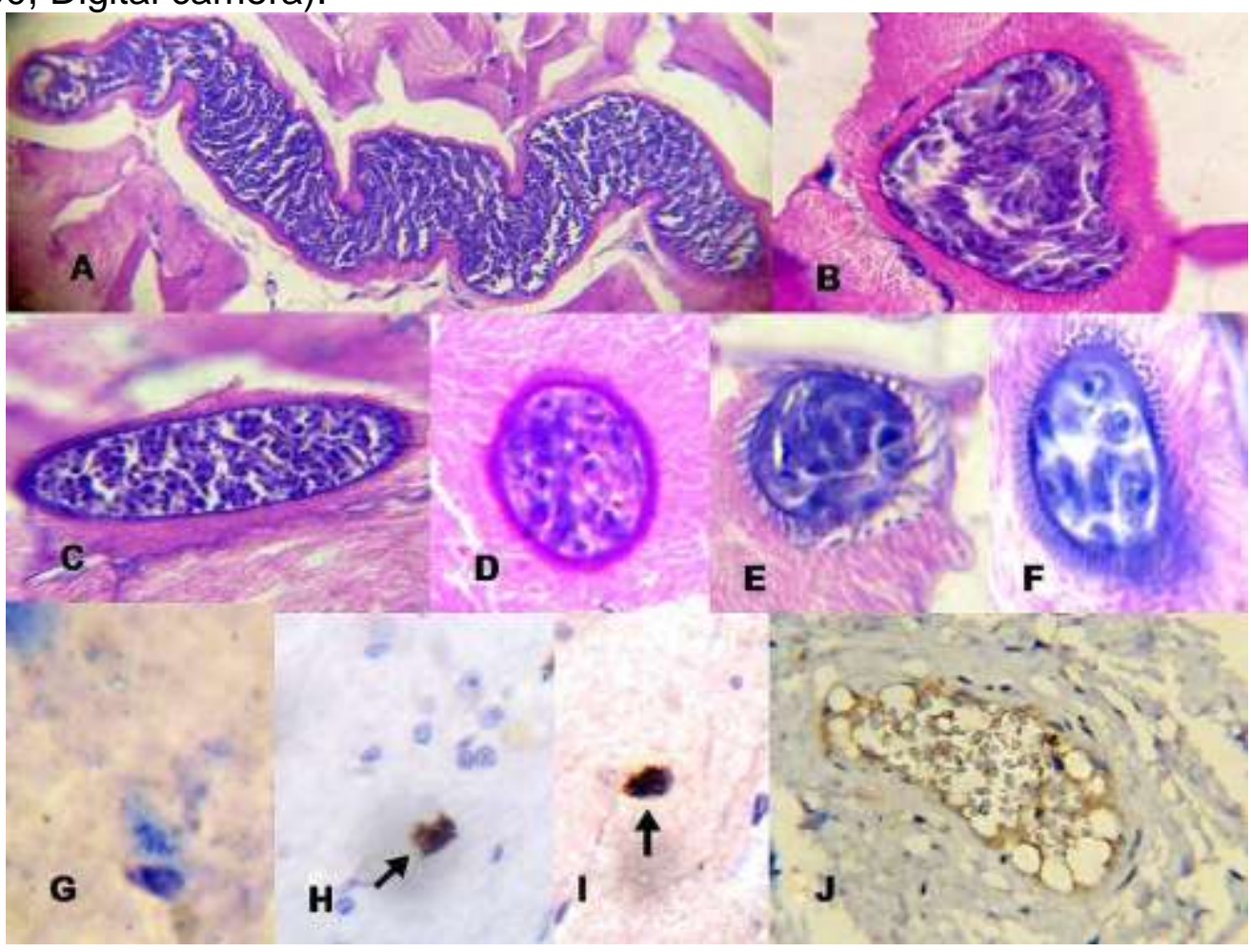

Fig. 2: Histopatholgical sections stained with H\&E for Sarcocystis spp. in donkeys. A: longitudinal section of $S$. bertrami with clear septa and thin walled 
cyst (X100); B: Cross section of $S$. equicanis showing ciliated and thin walled cyst (X100); C: Longitudinal section of $S$. fayeri mature cyst in meat samples showing thick and striated cyst wall (X100); D: Cross section of $S$. fayeri mature cyst (X100); E: Cross section of $S$. fayeri developed cyst (X400); F: Cross section of $S$. fayeri immature cyst contained metrocytes and surrounded by granular cyst wall (X400); G: stained brain smear with Giemsa showing developed metrocytes with granular basophilic nucleus (X1000); H\&l: Strong labeled schizonts of $S$. neurona obtained by IHC (X400) and J: IHC stained brain section showed strong labeled cyst wall and negative stained bradyzoites of $S$. neurona in donkeys ((X1000, Digital camera).

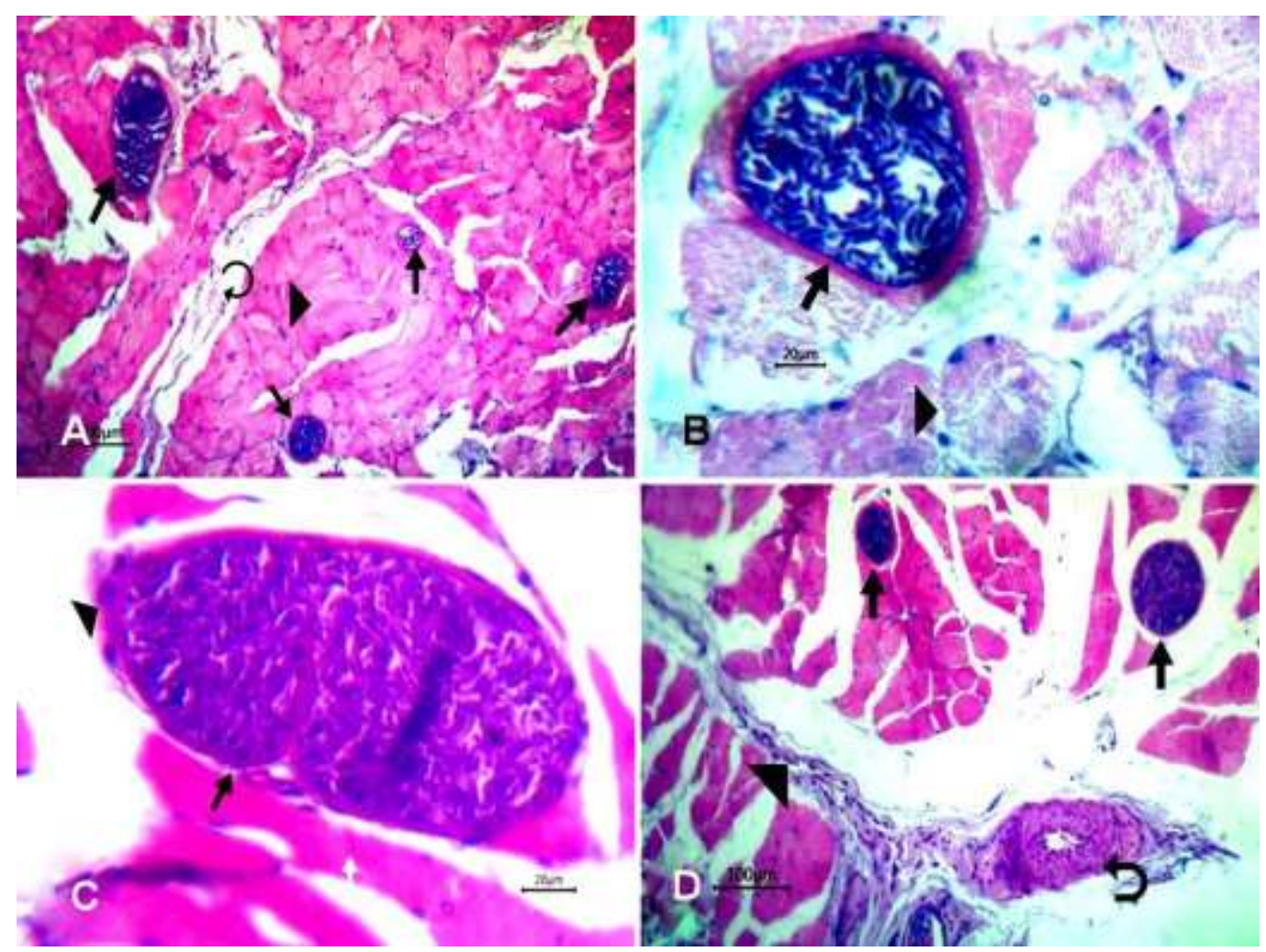

Fig.3: A: Heart showing multiple basophilic mature intramuscular cysts (arrow) between degenerated cardiac muscle (arrow head) with intermuscular edema (oblique arrow, bar=100); B: Heart showing cross section of $S$. fayeri (arrow) with acute muscle degeneration (arrow head, bar=20); C: Heart showing S. equicanis (arrow)among degenerated muscles (white arrow) with few number of mononuclear cells around cyst (arrow head, bar $=20$ ) and D:Heart showing two thin walled $S$. equicanis intramuscular cyst (arrow) with intermuscular edema (arrow head) and hyaline thickening of blood vessel wall together with endotheliosis (oblique arrow, bar =100). 


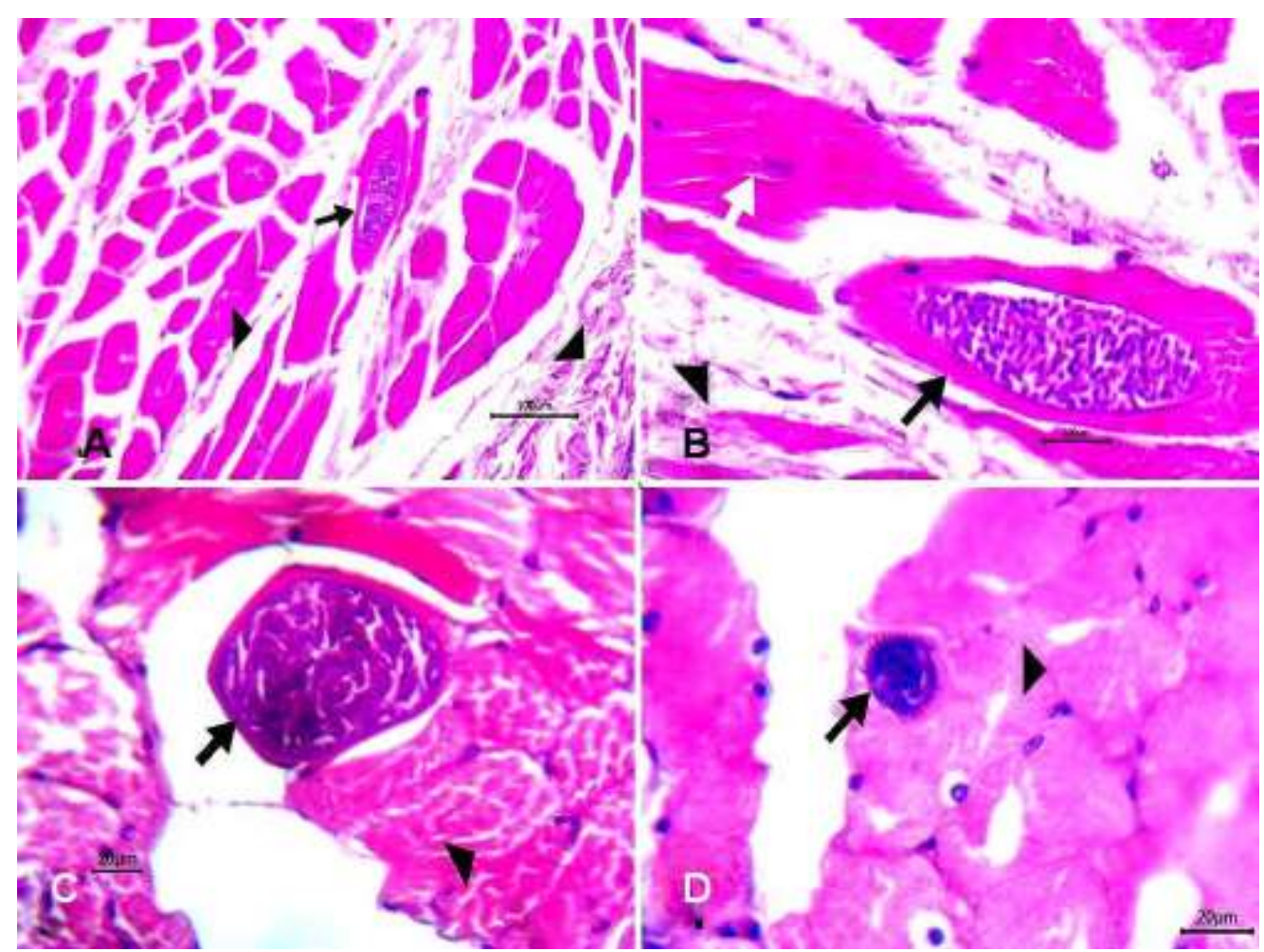

Fig. 4: A: Oesophagus showing elongated $S$. equicanis between muscle fibers (arrow) with intermuscular edema (arrow head, bar=100); B: Higher magnification of $S$. equicanis cyst (arrow) with degenerated muscle fibers (white arrow) and intermuscular edema (arrow head, bar=20); C: Oesophagus showing $S$. equicanis (arrow) with myofiber degeneration (arrow head, bar $=20$ ) and D: Oesophagus showing small sized developed cyst of $S$. fayeri (arrow) among degenerated muscles (arrow head, bar $=20$ ).

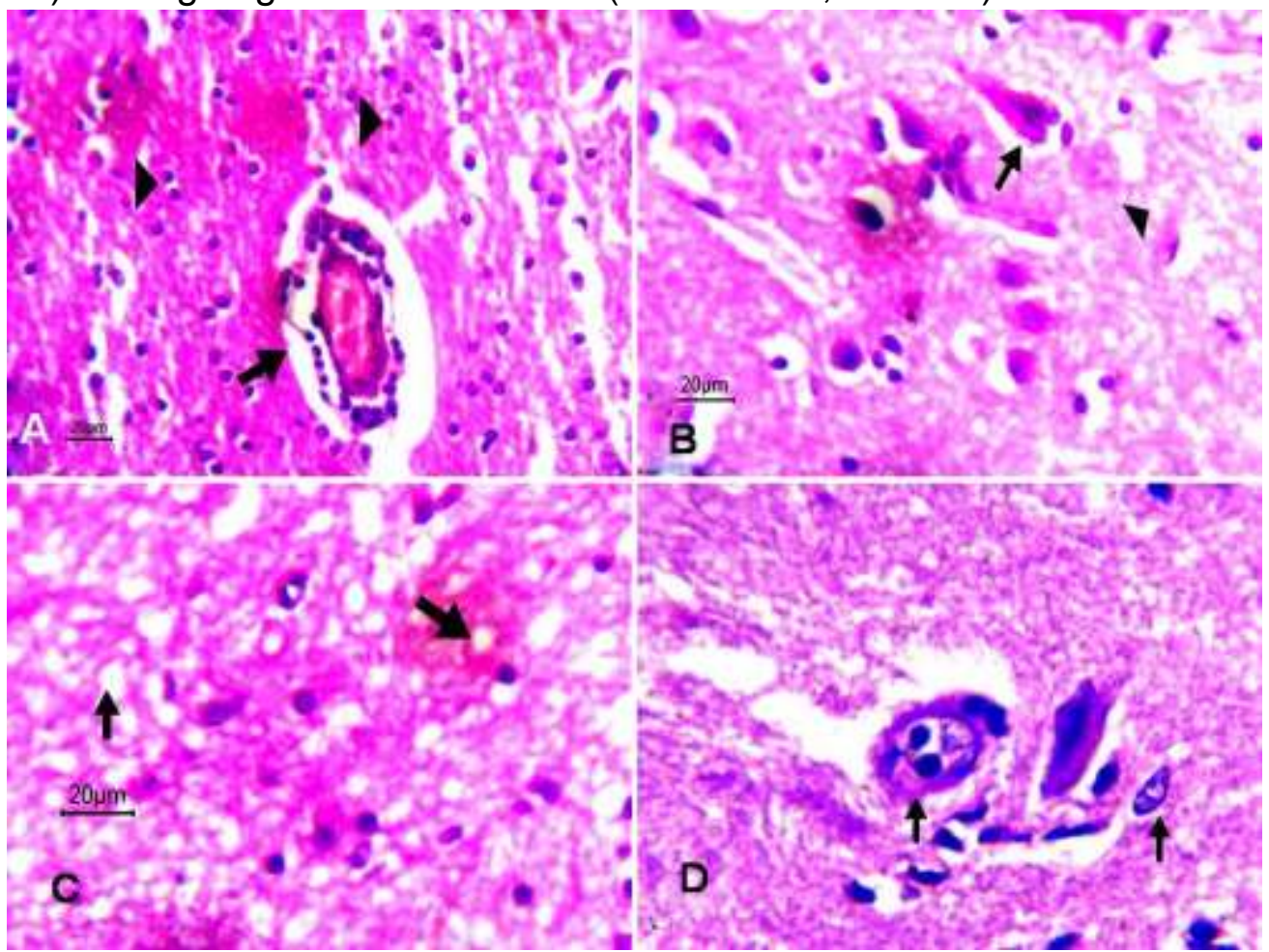

Fig. 5: A: Brain showing perivascular lymphocytic cuffing (arrow) with scattered glia cells in white and gray matter (arrow head, bar=20); B: Brain 
showing satellitosis (arrow) and demyelination in the white matter of brain tissue (arrowhead, bar=20); C: Brain showing encophalomalacia (arrow) with gliosis bar=20 and D: Brain showing developed merozoites (arrow

\section{Discussion}

The current study revealed that the total prevalence of Sarcocystis spp. in donkeys reached $73 \%$ by laboratory and IHC examination, while that obtained by Abdel- Maogood et al. 2015 reached $12 \%$ and $32 \%$ by PM examination and ELISA technique, respectively in Egypt. Also, it reached $66.66 \%$ in Egypt by Attia et al. 2018, $16.6 \%$ in Ethiopia by Woldemeskel and Gebreab, 1996.

Regarding S. bertrami, the recorded prevalence was $80.60 \%$, while in Italy it was $28.57 \%$ Passantino et al. 2019. The current study showed prevalence of $85.07 \%$ for $S$. equicanis, nearly similar rate was previously recorded in Egypt by Hilali and Nassar 1987 to be $90 \%$. This study is considered the first record of the prevalence of $S$. fayeri in donkeys which reached $50.75 \%$. In addition, the current study showed that the prevalence of $30 \%$ for $S$. neurona by IHC technique, while it was $2.5 \%$ by ELISA in Mexico Alvarado-Esquivel et al. 2017, $61.1 \%$ by immunoblot in USA by Saville et al. 1997, 3\% and $21 \%$ by indirect fluorescent antibody test (IFAT) and direct agglutination tests, respectively by Gennari et al. 2016 in Brazil.

The differences in the prevalence rates is not only due to different diagnostic methods (PM examination, ELISA, IFAT or IHC) or climatic changes, but also due to the differences in intermediate host species (horse or donkey), host susceptibility to infection, and exposure to the final hosts (dogs for Sarcocystis spp. in meat or opossums for $S$. neurona). The more opportunity of donkeys became in contact with final hosts, the more chance to acquire infection with Sarcocystis spp. Alvarado-Esquivel et al. 2017; Dubey et al. 2016a.

The obtained morphological descriptions for $S$. bertrami, $S$. equicanis/S. asinus, $S$. fayeri were similar to those noticed by Aleman et al. 2015; Dubey et al. 1989; Hilali and Nassar 1987; Saville et al. 2004; Zeng et al. 2018.

Zeng et al. 2018 found that horses and donkeys had the same Sarcocystis spp. They had been included S. bertrami, S. equicanis, $S$. fayeri and $S$. neurona. The previous study of Dubey et al. 2016b on donkey's sarcocytosis in Egypt recorded only $S$. bertrami in their meat, while the current study recorded four Sarcocystis spp. The current study described $S$. bertrami in donkeys as macroscopic cysts in spite of the previous description of $S$. bertrami in donkeys by Dubey et al. 2016b in Egypt as microscopic cysts. They also stated that smooth and ciliated parts were noticed in the same cyst of $S$. bertrami, while the currently studied appeared smooth thin walled macroscopic cysts in $S$. bertrami, ciliated microscopic thin walled cysts in S. equicanis/S. asinus and striated 
thick walled microscopic cysts in $S$. fayeri. S. equicanis cysts were noticed in the esophageal and cardiac muscles of donkeys, however inability of Sakran et al. 2013 to detect them in the cardiac muscles of horses in Egypt. Zeng et al. 2018 described 2 types of $S$. bertrami in horses and donkeys in China, where Type I cysts were large without protrusions (smooth) and Type II cysts were smaller with protrusions (ciliated) and referred that to the Type I might be aged cysts. However, Sheffield et al. 1977 stated that Sarcocystis spp. cysts increased in size with age, but their wall structure remained stable once the cysts become mature (contained bradyzoites). This confirmed our record for $S$. bertrami and $S$. equicanis as different species and they have not the same description as the previous ones Dubey et al. 2016a; Odening et al. 1995; Rommel and Geisel 1975. Also, we suggested that the previously described $S$. equicanis in horses is a synonym to the currently obtained $S$. asinus in donkeys depending upon their similarity with morphological characters.

In the current study, the cysts in brain were difficult to be identified in sections stained with $H$ \& E, but it was more easily noticed in sections reacted against polyclonal $S$. neurona antibody. Also, the schizonts were more easily identified in sections reacted against polyclonal $S$. neurona antibody than those in histological sections. These findings were similar to those of Lindsaya et al. 2000. The noticed morphological features of $S$. neurona in brain were agreed with those described by Seguel et al. 2019 in California sea lions. The observed variability in staining pattern between $S$. neurona cyst wall and bradyzoites resembled the recorded observations of Butcher et al. 2002 in domestic cats and Miller et al. 2009 in southern sea otters. Sakran et al. 2013 reported that $S$. neurona schizonts were observed only within the neural cells of brain in horses, while the current study observed both schizonts and cyst in brain of donkeys by IHC technique. Alvarado-Esquivel et al. 2017 reported the seroprevalence $(2.5 \%)$ of $S$. neurona in donkeys in Mexico, while the current study reported them for the first time in the brain of donkeys in Egypt. As mentioned in a previous study by Dubey et al. 2015 that the presence of mature cysts and schizonts in the brain of the same host indicated it as I.H. and not an aberrant host and so from our obtained results, the donkeys were considered I.H. for S. neurona, however horse considered an aberrant host Ma et al. 2020.

Sarcocystis spp. had been associated with myocarditis reaction. Hyaline thickening of the blood vessel with endotheliosis were observed due to localization of their schizonts in the endothelia of blood vessels (Yarim et al. 2004). In the current study, the heart and esophagus exhibited multiple basophilic mature round and elongated intra muscular cysts containing banana shape bradyzoites. Some cysts had thin wall and other had thick wall. These findings were completely agreed with Faghiri et al. 2019 who observed thin and thick walled cysts inside the cardiac and esophageal muscles. Also the obtained results detected few mononuclear inflammatory cells were present around the cysts. Acute 
degeneration of the cardiac muscle and intermuscular edema were detected. These findings were completely agreed with Caspari et al. 2011 who observed multifocal degeneration and necrosis of myocardial fibers with interstitial edema. Microscopical features of the brain revealed perivascular lymphocytic cuffing with scattered glia cells in the white and gray matter. Satellitosis and demyelination were detected in the white matter. Encophalomalacia represented by depletion of certain part of brain tissue with gliosis were observed. The developing schizonts of Sarcocystis spp. were also detected. These findings were partially agreed with (Özmen et al. 2009) where their histopathological examinations showed focal areas of perivascular cuffing in the brainstem, cerebellum, and medulla spinalis with presence of Sarcocystis spp. schizonts.

The current study concluded that the donkeys were considered I.H. for $S$. neurona in brain and for $S$. bertrami, $S$. equicanis/S. asinus, and $S$. fayeri in meat. Also, $S$. equicanis in horses is a synonym for $S$. asinus in donkeys. As the donkeys had great economic importance in Africa, the accurate recognition about Sarcocystis spp. in donkeys would be helpful in performance of prevention and control measures against future infections.

\section{References}

Abdel- Maogood, S.Z.; AbdelWahab, A.M. and Lilian, N.M. (2015): Improved dot ELISA technique for diagnosis of some tissue parasites infecting donkeys. Int. J. Chem.Tech. Res., 8 (12):94-103.

Aleman, M.; Shapiro, K.; Siso, S.; Williams, D.C.; Rejmanek, D.; Aguilar, B. and Conrad, P.A. (2015): Sarcocystis fayeri in skeletal muscle of horses with neuromuscular disease. Neuromuscul. Disord., 26 (1):85-93.

Alvarado-Esquivel, C.; Howe, D.K.; Yeargan, M.R.; Alvarado-Esquivel, D.; Zamarripa-Barboza, A.J. and Dubey, J.P. (2017): Seroepidemiology of Sarcocystis neurona and Neospora hughesi infections in domestic donkeys (Equus asinus) in Durango, Mexico. Parasit.,24:27.doi:10.1051/parasite/20 17030

Attia, M.M.; Khalifa, M.M. and Atwa, M.T. (2018): The prevalence and intensity of external and internal parasites in working donkeys (Equus asinus) in Egypt. Vet. World, 11 (9):1298-1306.

Butcher, M.; Lakritz, J.; Halany, A.; Branson, K.; Gupta, G.D.; Kreeger, J. and Marsh, A.E. (2002): Experimental inoculation of domestic cats (Felis domesticus) with Sarcocystis neurona or Sarcocystis neurona-like merozoites. Vet. Parasitol., 107:1-14.

Caspar,i K.; Grimm, F.; Kuhn, N.; Caspari, N.C. and Basso W. (2011): First report of naturally acquired clinical sarcocystosis in a pig breeding stock. Vet. Parasitol.,177 (1-2):175178.

Dubey, J.P.; Calero-Berna,I R.; Rosenthal, B.M.; Speer, C.A. and Fayer, R. (2016a): Sarcocystosis of animals and humans 2nd edn., CRC Press. Boca Raton, FL, USA.

Dubey, J.P.; Howe, D.K.; Furr, M.; Saville, W.J.; Marsh, A.E.; Reed, S.M. and Grigg, M.E. (2015): An 
update on Sarcocystis neurona infections in animals and equine protozoal myeloencephalitis (EPM). Vet. Parasitol., 209 (1-2):1-42.

Dubey, J.P.; Lindsay, D.S.; Saville, W.J.A.; Reed, S.M.; Granstrom, D.E. and Speer, C.A. (2001): A review of Sarcocystis neurona and equine protozoalmyeloencephalitis (EPM). Vet. Parasitol., 95:89-131.

Dubey, J.P.; Speer, C.A. and Fayer, R. (1989): Sarcocystosis of animals and man. 1st edn., CRC Press, Boca Raton, Florida.

Dubey, J.P.; Wilp,e E.V.; Verma, S.K. and Hilali, M. (2016b): Ultrastructure of Sarcocystis bertrami sarcocysts from a naturally infected donkey (Equus asinus) from Egypt. Parasitol., 143:18-33.

Faghiri, E.; Davari, A. and Nabavi, R. (2019): Histopathological survey on sarcocystis species infection in slaughtered cattle of Zabol-Iran. Turki. parazitol. dergisi., 43 (4):182-186.

Gennari, S.M.; Pena, H.F.; Lindsay, D.S.; Lopes, M.G.; Soares, H.S.; Cabral, A.D.; Vitaliano, S.N. and Amaku, M. (2016): Prevalence of antibodies against Neospora spp. and Sarcocystis neurona in donkeys from northeastern Brazil. Revista Brasil. de Parasitol. Vet., 25 (1):109-111.

Hilali, M. and Nassar, A.M. (1987): Ultrastructure of Sarcocystis spp. from donkeys (Equus asinus) in Egypt. Vet. Parasitol., 23:179-183.

Kiupel, M.; Simmons, H.A.; Fitzgerald, S.D.; Wise, A.; Sikarskie, J.G.; Cooley, T.M.; Hollamby, S.R. and Maes, R. (2003): West Nile virus infection in eastern fox squirrels (Sciurus niger). Vet. Pathol., 40:703707.
Levine, N.D. and Tadros, W. (1980): Named species and hosts of Sarcocystis (Protozoa: Apicomplexa: Sarcocystidae). Syst. Parasitol., 2:4159.

Lindsaya, D.S.; Thomasb, N.J. and Dubey, J.P. (2000): Biological characterisation of Sarcocystis neurona isolated from a Southern sea otter (Enhydra lutris nereis). Int. J. Parasitol.; 30:617-624.

Ma, C.L.; Ye, Y.L.; Wen, T.; Huang, Z.M.; Pan, J.; Hu, J.J.; Tao, J.P. and Song, J.L. (2020): Prevalence and morphological and molecular characteristics of Sarcocystis bertrami in horses in China. Parasit., 27:1. doi:10.1051/parasite/2019078

Miller, M.A.; Barr, B.C.; Nordhausen, R.; James, E.R.; Magargal, S.L.; Murray, M.; Conrad, P.A.; ToyChoutka, S.; Jessup, D.A. and Grigg, M.E. (2009): Ultrastructural and molecular confirmation of the development of Sarcocystis neurona tissue cysts in the central nervous system of southern sea otters (Enhydra lutris nereis). Int. J. Parasitol., 39 (12):1363-1372.

Odening, K.; Wesemeier, H.H.; Walter G.and Bockhardt, I. (1995): Ultrastructure of sarcocysts from equids. Acta. Parasitol., 40:12-20.

Özmen, Ö.; Şahlinduran, Ş.; Haligür, M.; Yukari, B.A.and Dorrestein, G.M. (2009): Encephalitic sarcocystosis and its prophylactic treatment in sheep. Turk. J. Vet. Anim. Sci., 33 (2):151155.

Passantino, G.; Lia, R.P.; Latrofa, S.; Annoscia, G.; Slapeta, J.; Otranto, D.; Rossi, R. and Zizzo, N. (2019): Sarcocystis bertrami in skeletal muscles of donkeys (Equus africanus asinus) from Southern Italy. Vet. 
Parasitol. Reg. Stud. Reports, 16:100283.doi:10.1016/j.vprsr.2019.10 0283

Rommel, M. and Geisel, O. (1975): Untersuchungen über die verbreitung und de lebenszyklus einer sarkosporidienart des pferdes (Sarcocystis equicanis n. spec.). Berl. und München. Tierärztl. Wochensch., 88:468-471

Sakran, T.; Al- Hroub, A. and Ahmed, A. (2013): Studies on Sarcocystis infecting domestic horse. Am. J. Res. Commun., 1 (6):39-35.

Saville, W.J.; Dubey, J.P.; Oglesbee, M.J.; Sofaly, C.D.; Marsh, A.E.; Elitsur, E.; Vianna, M.C.; Lindsay, D.S. and Reed, S.M. (2004): Experimental infection of ponies with Sarcocystis fayeri and differentiation from Sarcocystis neurona infections in horses. J. Parasitol., 90 (6):1487-1491.

Saville, W.J.; Reed, S.M.; Granstrom, D.E.; Hinchcliff, K.W.; Kohn, C.W.; Wittum, T.E. and Stamper, S. (1997): Seroprevalence of antibodies to Sarcocystis neurona in horses residing in Ohio. J. Am. Vet. Med. A., 210 (4):519-524.

Seguel, M.; Colegrove, K.M.; Field, C.; Whoriskey, S.; Norris, T. and Duignan, P. (2019): Polyphasic rhabdomyositis in California Sea Lions (Zalophus Californianus): Pathology and potential causes. Vet. Pathol.,56 (4):619-629.

Sheffield, H.G.; Frenkel, J.K. and Ruiz, A. (1977): Ultrastructure of the cyst of Sarcocystis muris. J. Parasitol.,63:629-641

Slapeta, J.R.; Modry, D. and Koudela, B. (1999): Sarcocystis atheridis sp. nov., a new sarcosporidian coccidium from Nitsche's bush viper, Atheris nitschei Tornier, 1902, from Uganda. Parasitol. Res., 85:758-764

Soldati, S.; Kiupel, M.; Wise, A.; Maes, R.; Botteron, C. and Robert, N. (2004): Meningoencephalomyelitis caused by Neospora caninum in a juvenile fallow deer (Dama dama). J. Vet. Med. A., 51:280-283.

Suvarna, S.K.; Layton, C, and Bancroft, J.D. (2013): Bancroft's theory and practice of Histological techniques. 7th edn., Churchill Livingstone, Elsevier, England.

Woldemeskel, M. and Gebreab, F. (1996): Prevalence of sarcocysts in livestock of Northwest Ethiopia. J. Vet. Med. B., 43:55-58.

Yarim, M.; Yildiz, K.; Kabakci, N. and Karahan, S. (2004): Immunohistochemical localisation of 3beta-hydroxysteroid dehydrogenase in Sarcocystis spp. Parasitol. Res., 93 (6):457-460.

Zeng, W.; Sun, L.; Xiang, Z.; Li, N.; Zhang, J.; He, Y.; Li, Q.; Yang, F.; Song, J.; Morris, J.; Rosenthal, B.M.; Sun, L.; Liu, H. and Yang, Z. (2018): Morphological and molecular characteristics of Sarcocystis bertrami from horses and donkeys in China. Vet. Parasitol., 252:89-94. 


\section{الملخص العربي \\ الخصائص المظهرية والنسيجية لمختلف أنواع الساركوسيستيس في الحمير \\ "منى محمد إبر اهيم عبدالرحمن -*** هبه محمد عبدالغنى}

"قسم الطفيليات و **الباتولوجيا -كلية الطب البيطرى- جامعة الزقازيق

درس العديد من المؤلفين النسابقين طفيل النساركوسيستس في الخيول ، ولكن لايتوفر سوى القليل من الدراسات عنها فى الحمير ولذلك فقد هدفت هذه الدر اسة إلى تسجيل معدلات انتشار الانواع المختلفة من طفيل الساركوسيستس وتوضيح خصائصها المورفولوجية من خلال التقنيات المختبرية والفصح الباثولوجى و الكيميائى المناعى وكذلك دراسه التغيرات النسيجيه الباثولوجيه في عينات المريء و القب و الاماغ التى تم تجميعها من الحمير المصابة طبيعيا في مصر . وقد تمكنت الدر اسة الحالية من التعرف على أربعة أنو اع من ساركوسيستس بيرتر امى و فاييرى و اكوى كانيز فى عضلات الحمير و ايضا النوع نيرونا في ادمغه الحميز المصابه وقد تم تصنيفها طبقا لسمك جدار الحويصلات حيث كانت ذات جدران رثقة ناعمة للنوع ساركوسيستس بيرتر امى و رقيقة ذات اهداب فى النوع اكوى كانيز و سميكه فى ساركوسيستس فاييرى وقد أوضح الفحص الكيميائي المناعي للنوع نيرونا تفاعل ايجابى لكل من الثشيزونت و الجدار الخارجى للحويصلات بينما البر اديزويت كانت ذات تفاعل سلبى. وقد اوضح الفحص النسيجى عن انحطاط العضلات ذات الوذمة العضلية و عدد قليل من الخلايا الالتهابية أحادية النواة ولكن أنسجة الدماغ أظهرت تضخم اللمفاويات حول الاو عبه الذمويه وداء الاقمار الصناعيه وبالتالى فان الدر أسه الحاليه تستخلص ان الحمير تعد عائل وسيط للنيرونا على عكس الخيول وأيضدا قد بشكل التعرف الأقيق على أنواع حويصلات السـاركوسيتس اهميه كييره فى تحديد العلاج اللازم وكذلك و الوقاية منها و السيطرة عليها 
